Review

\title{
Zirconia versus titanium in dentistry: A review
}

\author{
Takao HANAWA \\ Institute of Biomaterials and Bioengineering, Tokyo Medical and Dental University, 2-3-10 Kanda-surugadai, Chiyoda-ku, Tokyo 101-0062, Japan \\ Corresponding author, Takao HANAWA; E-mail: hanawa.met@tmd.ac.jp
}

\begin{abstract}
This review scientifically compares the properties of zirconia and titanium, but does not identify the best among them as an implant material. Surface treatment and modification to improve tissue bonding and inhibit bacterial adhesion are not considered in this review. The mechanical properties of titanium are superior to those of zirconia; some studies have shown that zirconia can be used as a dental implant, especially as an abutment. Extensive surface treatment research is ongoing to inhibit bacterial adhesion and improve osseointegration and soft tissue adhesion phenomena which make it difficult to evaluate properties of the materials themselves without surface treatment. Osseointegration of titanium is superior to that of zirconia itself without surface treatment; after surface treatment, both materials show comparable osseointegration. The surface morphology is more important for osseointegration than the surface composition. To inhibit bacterial adhesion, zirconia is superior to titanium, and hence, more suitable for abutments. Both materials show similar capability for soft tissue adhesion.
\end{abstract}

Keywords: Zirconia, Titanium, Bacterial adhesion, Osseointegration, Soft tissue adhesion

\section{INTRODUCTION}

Metal-free treatment is now popular in dentistry due to the esthetic problem of metal restoratives. Metals have long been used for dental restoratives. In dentistry, esthetics is among the predominant goals. Therefore, even if the mechanical properties of a material are insufficient, its esthetics is sometimes preferred. Metals or metallic materials are defined as "materials consisting of metallic bonds." One of the characteristics of metals is metallic luster due to these metallic bonds. This disadvantage of metals has led to their substitution by ceramics and polymers in dentistry. There are always discussions and debates on material selection among dentists, manufacturers, and dental materials researchers. However, these discussions, debates may not always be based on scientific viewpoints such as materials science and engineering. Among the causes for debates is the propaganda from manufacturers which only highlight the merits of products that is believed by most of dentists and some of researchers. An interesting theme of recent debates is the selection of zirconia or titanium as dental implants. Comparing zirconia to titanium is almost equivalent to comparing ceramics with metals. The advantages of ceramics are high-temperature resistance, wear resistance, chemical stability, and importantly, white color for dentistry, while the disadvantages include low fracture toughness or brittleness. On the other hand, the advantages of metals are high fracture toughness based on high strength and elongation and good balance between rigidity and stiffness, while the disadvantages include corrosion and fatigue. As is well known, all materials have advantages and disadvantages; there is no material that shows only advantages. In this review, a scientific comparison of the properties of zirconia and titanium is attempted, but the best among them as an implant material is not judged.
Surface treatment and modification to improve tissue compatibility and inhibit bacterial adhesion are not considered in this review; nevertheless, recent research on tissue compatibility has focused on evaluation after surface treatment involving the surface morphology. In this review, the terms "zirconia" and "titanium" are used for general and comprehensive material names, while $\mathrm{ZrO}_{2}$ and $\mathrm{Ti}$ are used when the compositions are clear.

\section{OVERVIEW OF ZIRCONIA AND TITANIUM}

\section{Zirconia}

Zirconia was originally discovered as a mineral in $1892^{1)}$, and has been widely used as a refractory material for applications such as the outer wall of space shuttles owing to its high melting point of $2,715^{\circ} \mathrm{C}$. The most stable phase at ambient temperature is monoclinic, which, upon heating, transforms into tetragonal and cubic phases ${ }^{2}$. However, when sintered zirconia is cooled to ambient temperature, cracks are formed in zirconia due to the volume increase from the tetragonal phase to the monoclinic phase, which decreases the mechanical strength of zirconia ${ }^{3)}$. The history of zirconia and its application to medicine and dentistry are summarized in Table 1.

Many researchers have found that small amounts of calcia $(\mathrm{CaO})$, magnesia $(\mathrm{MgO})$, ceria $\left(\mathrm{CeO}_{2}\right)$, and yttria $\left(\mathrm{Y}_{2} \mathrm{O}_{3}\right)$ in a solid solution of $\mathrm{ZrO}_{2}$ can stabilize the tetragonal or cubic phase of $\mathrm{ZrO}_{2}$ at ambient temperature, depending on the amount of oxide added. Fully stabilized zirconia (FSZ), consisting of only the cubic phase, shows the greatest ion conductivity and has been used in solid oxide fuel cells and oxygen sensors. On the other hand, partially stabilized zirconia (PSZ) contains the monoclinic or tetragonal phase in addition to the cubic phase. Classical theory shows that the strain energy of the surrounding material allows the 
Table 1 History of zirconia application to medicine

\begin{tabular}{cll}
\hline Year & \multicolumn{1}{c}{ Material } & \multicolumn{1}{c}{ Event and application } \\
\hline 1892 & $\mathrm{ZrO}_{2}$ mineral & Discovery \\
1929 & Stabilized zirconia: Polycrystalline ceramics & Development \\
1937 & Cubic zirconia in the form of microscopic grains & Development \\
1969 & Application to medicine & First paper of zirconia for medical use \\
1973 & Skull crucible process & Development \\
1975 & $\begin{array}{l}\text { Ceramic steel: Zirconia consisting of tetragonal } \\
\text { phase within large cubic-phase grains (PSZ) }\end{array}$ & Development \\
1976 & Commercial production & \\
1977 & Y-TZP & Highest mechanical strength of 690 MPa \\
1985 & Y-TZP & Clinically marketed as the ball head of \\
2001 & Marketed dental restoratives & $\begin{array}{l}\text { an artificial hip joint } \\
\text { CAD/CAM system, Dentsply Sirona }\end{array}$ \\
2005 & Marketed dental restoratives in Japan & CAD/CAM system, Dentsply Sirona \\
2006 & Zirconia implant & Abutment
\end{tabular}

tetragonal or cubic structure to be retained. The surface tension associated with the decreased particle size of the crystal restricts the transformation from the cubic phase into the tetragonal phase and the following monoclinic phase $^{4,5)}$.

In $1975, \mathrm{ZrO}_{2}$ comprising a tetragonal phase within large cubic-phase grains showed a high transverse rupture strength of $650 \mathrm{MPa}$ in a four-point bending test, whereas pure monoclinic $\mathrm{ZrO}_{2}$ showed a strength of $250 \mathrm{MPa}^{3,6}$. The mechanism of this high mechanical strength was as follows: When stress is added to zirconia by micro-cracking, the constraint strain energy of the metastable tetragonal phase decreases. The tetragonal phase transforms into the monoclinic phase accompanied by a volume increase of $3-4 \%$, which generates resistance stress against the propagation of micro-cracks in zirconia ${ }^{7}$. In 1977, a yttria-stabilized tetragonal zirconia polycrystalline (Y-TZP), including $98 \%$ of the tetragonal phase obtained by introducing a small amount of $\mathrm{Y}_{2} \mathrm{O}_{3}$, showed the highest mechanical strength of $690 \mathrm{MPa}$ among the tested samples ranging from 10 to $98 \%$ tetragonal $\mathrm{ZrO}_{2}{ }^{8,9)}$. The bending strength increased by refining the density, grain size, and sintering conditions, and the fracture toughness was higher than that of alumina $\left(\mathrm{Al}_{2} \mathrm{O}_{3}\right)$, which was used for the ball head of artificial hip joints. In terms of bending strength, $\mathrm{Y}_{2} \mathrm{O}_{3}$ was selected as an additive oxide in zirconia and Y-TZP became the major material for the ball head ${ }^{10-12)}$.

In 1985, Y-TZP was clinically marketed as the ball head of an artificial hip joint in France ${ }^{13)}$ after the first paper regarding the application of zirconia for medical science was published in 196914). Besides its bending strength, Y-TZP is less likely to induce allergic hypersensitivity. Clinical Y-TZP comprises nearly $100 \%$ of the tetragonal phase of $\mathrm{ZrO}_{2}$ stabilized by approximately $3 \mathrm{~mol} \%$ of $\mathrm{Y}_{2} \mathrm{O}_{3}$ in a solid solution of $\mathrm{ZrO}_{2}$.

Y-TZP has an esthetic white color and translucency similar to human teeth, whereas the metal implanted in a tissue makes the soft tissue look gray ${ }^{15,16)}$. Therefore, Y-TZP has become a major ceramic material in dentistry over the past two decades due to its white color and sufficient mechanical strength. When we need to restore decayed teeth with an inlay or a crown, at present, we can choose metallic or ceramic prosthesis by considering the color and biocompatibility. This is because Y-TZP is widely available for use as inlays, crowns, bridges, and abutments, which connect roots and artificial teeth in dental implants.

\section{Titanium}

The history of application of commercially pure titanium (CP Ti) and titanium alloys (Ti alloys) to medicine and dentistry is summarized in Table 2. The first report on CP Ti for medicine was presented in 1940, demonstrating excellent bone compatibility in an animal test ${ }^{17)}$. Thereafter, compatibility to bone and soft tissue of rabbits ${ }^{18)}$, non-cytotoxicity due to excellent corrosion resistance in biological environment ${ }^{19)}$, and excellent biocompatibility in dogs were reported. A large-scale industrial manufacturing process of titanium was achieved by the latter half of the 1940s, which made it possible to conduct considerable research for medical applications, owing to the excellent biocompatibility revealed in a long-term animal test ${ }^{20)}$. Thereafter, the usefulness of CP Ti was widely recognized by the latter half of the 1960s through clinical evaluation ${ }^{20-22}$.

On the other hand, to avoid the fracture of $\mathrm{CP}$ $\mathrm{Ti}$ in the human body, an aerospace Ti-6Al-4V alloy was diverted to artificial joints and bone fixators ${ }^{20-22)}$. 
Table 2 History of titanium application to medicine and development of titanium alloys

\begin{tabular}{|c|c|c|c|}
\hline Year & Material & Event and application & Reference \\
\hline 1791 & Ti element in ore & Discovery of menachite, ore of titanium & \\
\hline 1795 & Ti element in ore & Named as titan & \\
\hline 1910 & $\mathrm{Ti}$ & $99.9 \% \mathrm{Ti}$ is smelled by Hunter & \\
\hline 1940 & $\mathrm{Ti}$ & $\begin{array}{l}\text { Confirmation of equivalent biocompatibility as stainless } \\
\text { steel and cobalt-chromium alloy with animal test }\end{array}$ & 17) \\
\hline 1940 & $\mathrm{Ti}$ & Success of smelting by Kroll process & \\
\hline 1948 & $\mathrm{Ti}$ & Launch of industrial production & \\
\hline 1951 & $\mathrm{Ti}$ & $\begin{array}{l}\text { Confirmation of both soft and hard tissue compatibility } \\
\text { with animal test }\end{array}$ & 18) \\
\hline 1957 & $\mathrm{Ti}$ & Confirmation of non-toxicity with long-term implantation & 19) \\
\hline 1959 & $\mathrm{Ti}-\mathrm{Ni}$ & Development of shape memory alloy in USA & 25) \\
\hline 1960 & $\mathrm{Ti}$ & Excellent results in artificial joints & 20) \\
\hline 1960’s & $\mathrm{Ti}$ & Marketing as surgical implants in UK and USA & \\
\hline 1970’s & Ti-6Al-4V & Diverting aircraft material to orthopedic implants & \\
\hline 1978 & $\mathrm{Ti}-\mathrm{Cu}-\mathrm{Ni}$ & Trial of dental casting & 30) \\
\hline 1980 & $\mathrm{Ti}-5 \mathrm{Al}-2.5 \mathrm{Fe}$ & Development in Europe & \\
\hline 1982 & $\mathrm{Ti}$ & $\begin{array}{l}\text { Development of investment material and casting machine } \\
\text { for dental casting }\end{array}$ & 31) \\
\hline 1985 & Ti-6Al-7Nb & Development in Switzerland & 23) \\
\hline 1993 & $\mathrm{Ti}-13 \mathrm{Nb}-13 \mathrm{Zr}$ & Development in USA & \\
\hline 1993 & Ti-12Mo-6Zr-2Fe & Development in USA & 25) \\
\hline 1996 & Ti-15Mo & Development in USA & 26) \\
\hline 1998 & $\mathrm{Ti}-29 \mathrm{Nb}-13 \mathrm{Ta}-4.6 \mathrm{Zr}$ & Development in Japan & 28) \\
\hline $\begin{array}{l}\text { Around } \\
2000\end{array}$ & Ti-15Mo-5Zr-3Al & Development in Japan & $\begin{array}{l}\text { Kobe Steel } \\
24)\end{array}$ \\
\hline
\end{tabular}

Thereafter, vanadium (V)- and/or aluminum (Al)-free $\alpha+\beta$-type Ti alloys and $\beta$-type Ti alloys with low Young's modulus were developed. $\mathrm{V}$, which shows cytotoxicity in Ti-6Al-4V alloy, was replaced by niobium $(\mathrm{Nb})$, which is a safe element for developing a new $\alpha+\beta$-type Ti-6Al-7Nb alloy $^{23)}$. Other $\alpha+\beta$-type alloys, Ti-6Al-2.5 iron (Fe) and Ti-6Al-2Nb-1 tantalum (Ta)-0.8 molybdenum (Mo), were developed in the $1970 \mathrm{~s}^{24)}$.

On the other hand, $\beta$-type Ti alloys have been developed for medical use. Ti-13zirconium (Zr)-13Ta alloy (nearly $\beta$ ), as well as various $\beta$-type alloys, Ti-12Mo$6 \mathrm{Zr}-2 \mathrm{Fe}$ alloys $^{25)}$, T-15Mo alloy ${ }^{26)}$, and Ti-15Mo-2.8Nb0.2 silicon- 0.28 oxygen $(\mathrm{O})$ alloy ${ }^{27)}$, have been developed in the United States. Ti-15Mo-5Zr and Ti-15Mo-5Zr$3 \mathrm{Al}$ alloys ${ }^{24)}$ and Ti-29Nb-13Ta-4.6Zr alloy ${ }^{28)}$ have been developed in Japan. The history of development of $\beta$-type Ti alloys is well-summarized elsewhere ${ }^{29)}$. Young's modulus can decrease to 40-60 GPa in a $\beta$-type alloy.

In dentistry, CP Ti has been successfully performed as dental implants since $1965^{30}$. In 1982 , a magnesiasystem investment and argon-arc casting machine were developed, followed by the development of various dental-casting systems ${ }^{31)}$.

\section{MECHANICAL PROPERTIES BASED ON CRYSTAL STRUCTURE}

\section{Crystal structure of zirconia}

The structure of zirconia has been reviewed elsewhere ${ }^{32)}$. Y-TZP exhibits a high flexural strength ${ }^{6,33-35)}$, which increases with surface modification ${ }^{36)}$. The fracture strength of one-piece zirconia implants is decreased with the preparation and cyclic loading. However, the resultant values are still within clinically acceptable limits ${ }^{37)}$. $\mathrm{ZrO}_{2}$ is a polymorphic material and forms three structures, monoclinic, tetragonal, and cubic, as shown in Fig. 1. The monoclinic phase is stable at ambient temperatures of up to $1,170^{\circ} \mathrm{C}$, the tetragonal phase is 


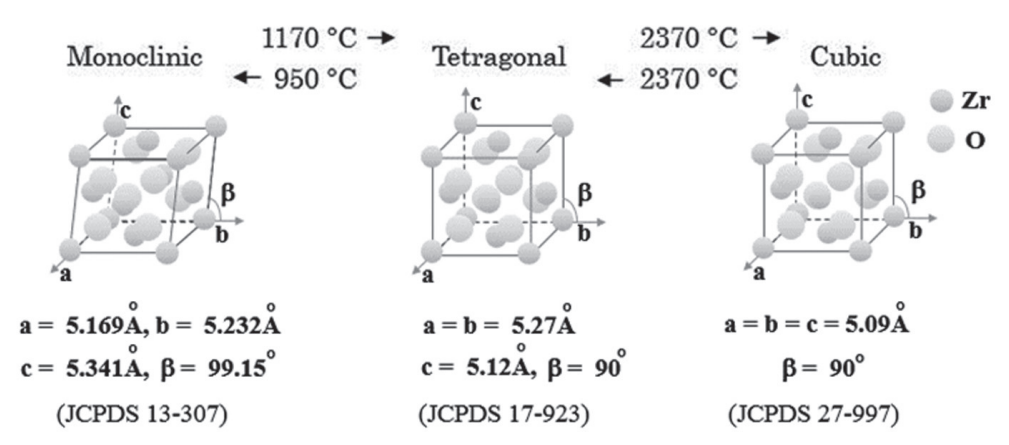

Fig. 1 Phase transformation of pure $\mathrm{ZrO}_{2}$ by temperature.

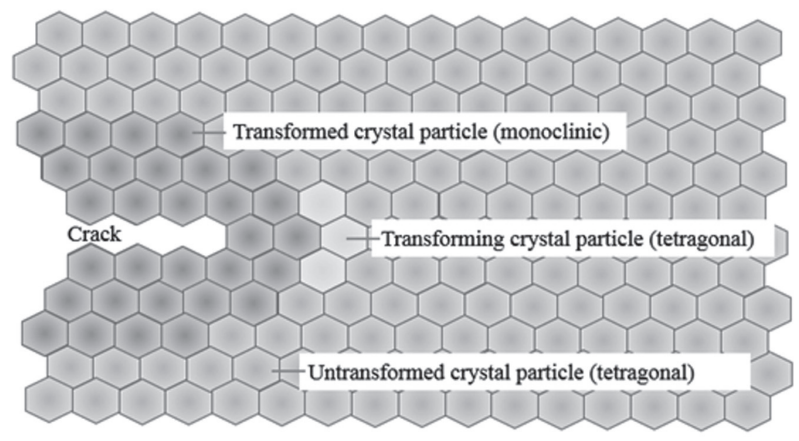

Fig. 2 Schematic of stress-induced transformation from tetragonal phase to monoclinic phase, generating resistance to micro-crack extension.

stable at temperatures of $1,170-2,370^{\circ} \mathrm{C}$, and the cubic phase is stable over $2,370^{\circ} \mathrm{C}^{38,39}$. A mixture of stabilizing oxides such as $\mathrm{CaO}, \mathrm{MgO}, \mathrm{Y}_{2} \mathrm{O}_{3}$, or $\mathrm{CeO}_{2}$ allows transformation to the metastable tetragonal structure at ambient temperature. Grinding or sandblasting in dental treatment generates a tetragonal to monoclinic transformation in the surface ${ }^{33)}$. The volume is expanded by the transformation from the tetragonal phase to the monoclinic phase. This phase transformation results in compression of cracks, thereby retarding its growth and enhancing fracture toughness (Fig. 2). This mechanism is well-known as transformation toughening ${ }^{40)}$. Zirconia possibly transforms to the monoclinic phase with moisture and stress, which is a demerit for dental implants. This mechanical degradation is known as "aging"39). Transformation to the monoclinic phase reduces strength, toughness, and density, which in turn leads to micro-cracking on the surface. This microcrack helps water penetration and causes corrosion ${ }^{41}$. Degradation at ambient temperature of Y-TZP involves roughening, increased wear and micro-cracking, grain pull-out, generation of particle debris, and premature failure $^{42)}$. The aging process depends on factors such as porosity, residual stress, grain size, and the content of the stabilizer ${ }^{43}$. Aging affects the mechanical properties of zirconia in vitro, even though the values are within clinically acceptable limits ${ }^{44,45)}$.

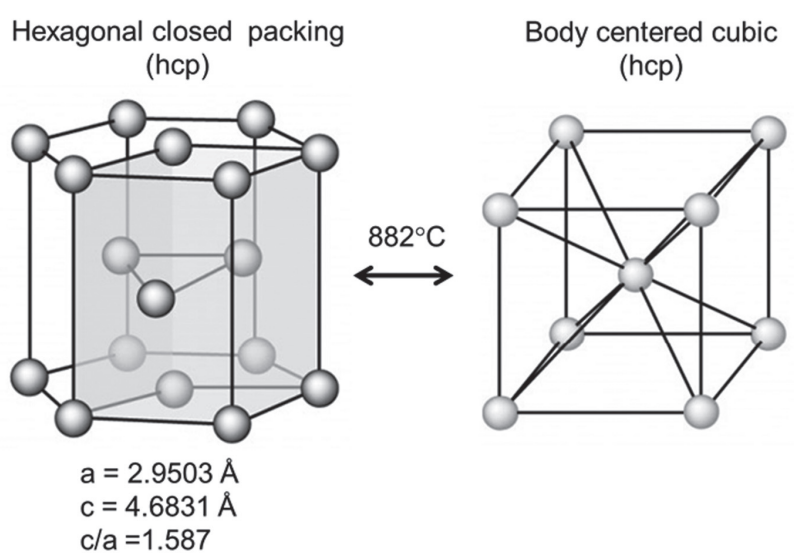

Fig. 3 Phase transformation of titanium by temperature.

\section{Crystal structure of titanium}

The crystal structures of the CP $\mathrm{Ti}$ and $\mathrm{Ti}$ alloys can be obtained from books ${ }^{46,47)}$. CP Ti is composed of hcp crystals ( $\alpha$ phase) at ambient temperatures and of bcc crystals ( $\beta$ phase) over $882^{\circ} \mathrm{C}$, as shown in Fig. 3 . Real pure Ti does not exist, because Ti easily dissolves impurities such as $\mathrm{O}$, carbon $(\mathrm{C})$, and nitrogen $(\mathrm{N})$ from the environment. Pure Ti containing these impurities is called $\mathrm{CP} \mathrm{Ti}$, which is classified into four grades according to its impurity content and the resulting mechanical properties. The higher the grade number and impurity, the higher is the tensile strength and offset yield stress and lower is the elongation. CP $\mathrm{Ti}$ is used for applications such as maxillofacial prosthetic plates, miniplates, sternal wires, and dental implants.

Ti alloys are categorized as $\alpha$-type, $\alpha+\beta$-type, and $\beta$-type alloys, according to the quantities and types of their alloying elements. Various alloys have been developed but the Ti- $6 \mathrm{Al}-4 \mathrm{~V}$ alloy, an $\alpha+\beta$-type alloy, is the most conventional one for medical use. This alloy shows good workability, heat treatment ability, and weldability, as well as corrosion resistance, strength, and biocompatibility. The extra low-interstitial (ELI)grade alloy, containing small amounts of interstitial impurities ( $\mathrm{O}, \mathrm{C}$, and $\mathrm{N})$, is used for biomaterials. The Ti-6Al-4V ELI alloy shows great toughness because the impurities decrease the fatigue strength with the notch 
Table 3 Mechanical properties of zirconia and titanium

\begin{tabular}{llcr}
\hline Mechanical property & Y-TZP & CP Ti (Grade 2) & Ti-6Al-4V Alloy \\
\hline Tensile strength $(\mathrm{MPa})$ & - & 345 & 860 (annealed) \\
Bending strength $(\mathrm{MPa})$ & 1,100 (without HIP) & 400 & 950 \\
Young's modulus $(\mathrm{GPa})$ & 1,800 (with HIP) & 100 & 110 \\
Vickers Hardness $(\mathrm{HV})$ & 210 & $150-170$ & $270-320$ \\
Fracture toughness $\left(\mathrm{MPa} \mathrm{m}{ }^{1 / 2}\right)$ & 1,200 & 66 & 50 \\
\hline
\end{tabular}

effect. The ELI alloy is used for bone fixation plates, screws, bone nails, and the stems of artificial hip joints. Ti-6Al-4V alloy has an extremely large $0.2 \%$ offset yield strength of $895 \mathrm{MPa}$, which is much larger than that of stainless steel and Co-Cr-Mo alloys, making plastic deformation difficult even under a large load. Ti alloys contain not only $\alpha$ and $\beta$ phases but also $\alpha$, $\alpha$ ", and $\omega$ metastable phases, which influences the mechanical property.

\section{Mechanical properties}

The mechanical properties of Y-TZP, CP Ti, and Ti-6Al$4 \mathrm{~V}$ alloys are summarized in Table 3.

Usually, it is impossible to conduct a tensile test for brittle materials such as ceramics, so only a compressive or bending test is conducted to evaluate the strength of ceramics. Therefore, it is difficult to directly compare the strength of ceramics with metals, whose strength is evaluated with a tensile test. The bending strength of Y-TZP is 1,000 MPa, which itself is sufficiently large in both Y-TZP and Ti for dental use. However, the strength of zirconia is good, but comparatively lesser than that of titanium $^{32)}$

The fracture toughness, $K_{\mathrm{IC}}$, of Y-TZP is 6-8 $\mathrm{MPa} \mathrm{m}{ }^{1 / 2}$, which is much higher than that of $\mathrm{Al}_{2} \mathrm{O}_{3}$, at 3.1-5.5 $\mathrm{MPa} \mathrm{m}{ }^{1 / 2}$. Therefore, Y-TZP is believed to be a high-fracture-toughness material, and called "white metal." However, this toughness value is still one order smaller than that of $\mathrm{CP} \mathrm{Ti}$, at $66 \mathrm{MPa} \mathrm{m}^{1 / 2}$. In addition, the notch stability is generally low in ceramics. Onepiece zirconia abutments exhibit a significantly lower fracture resistance than titanium abutments. The mode of failure is specific to the abutment material and design, with the zirconia abutment fracturing before the retentive abutment screw $^{48)}$.

There is no periodontal ligament between the implant fixture and alveolar bone, so the absorption of occlusal force is necessary. Therefore, Young's modulus is an important property for dental implants because materials with low Young's modulus can absorb occlusal pressure and occlusal force is not conducted directly to the alveolar bone. The Young's modulus for CP Ti and $\alpha+\beta$-type Ti alloys is $100-110 \mathrm{GPa}$ and that of $\beta$-type Ti alloys is 40-90 GPa. However, $\beta$-type Ti alloys show small strength. It is difficult to simultaneously obtain both small Young's modulus and large tensile strength.
On the other hand, Young's modulus of $\mathrm{ZrO}_{2}$ is $210 \mathrm{GPa}$, which increases with the increase in the strength of $\mathrm{Y}_{2} \mathrm{O}_{3}$ up to $280 \mathrm{GPa}$.

A large Young's modulus generates the difficulty of fastening screw because screwing fixation is achieved by the elastic deformation of a screw. In abutment, the screwing part is sometimes loosened because the screw fixation is achieved by the elastic deformation of the screwing material and substrate material. The axial force generated by elastic deformation is predominant to the fix. Therefore, Y-TZP has a problem of fixation by screwing.

\section{CHEMICAL STABILITY AND REACTIVITY}

\section{Zirconia}

Zirconia is categorized as an inert ceramic, as per all biomaterials textbooks. Therefore, to improve adhesion strength to bonding reagents, the surfaces of Y-TZP are treated by mechanical surface modification ${ }^{49,50)}$ followed by chemical surface treatment ${ }^{51,52)}$. The commonly used mechanical surface modifications include $\mathrm{Al}_{2} \mathrm{O}_{3}$ sandblasting or tribochemical silica coating. The surface is then cleaned by alcohol and water, and then dried. Thereafter, the chemical surface treatment is performed by applying a primer treatment, including 10methacryloyloxydecyl dihydrogen phosphate (MDP) ${ }^{53,54)}$. The phosphate groups of MDP interact with the hydroxyl groups on the zirconia surface by hydrogen bonding. The problem with this treatment is that it may decrease the durability of zirconia by creating micro-cracks or inducing a phase transformation on the Y-TZP surface. Closer investigations of the zirconia surface may provide insight into the surface treatment process. Zirconia does not bond to other materials without surface treatment.

Metal oxides including $\mathrm{ZrO}_{2}$ form hydroxyl groups on themselves because of a reaction with moisture in the air, as shown in Fig. $4 \mathrm{~A}^{55)}$. These hydroxyl groups dissociate in aqueous solutions, such as body fluid, to form electric charges $^{55-57)}$. These charges depend on the $\mathrm{pH}$ of the surrounding solution, and are balanced between positive and negative at a certain $\mathrm{pH}$, as shown in Fig. 4B. This $\mathrm{pH}$ is defined as the point of zero charge (PZC), which is a unique value depending on each oxide and an indicator of the acidic or basic property of the surface. For $\mathrm{ZrO}_{2}$, PZC is 3.6-4.2 $2^{58)}$. Therefore, the surface of $\mathrm{ZrO}_{2}$ in the 


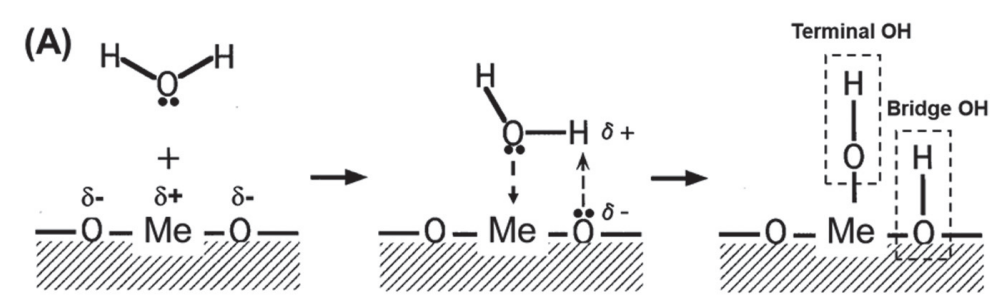

(B)

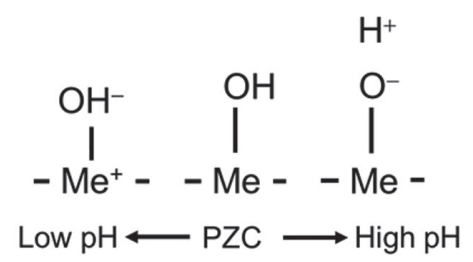

Fig. 4 Formation of hydroxyl group on metal oxide (A) and dissociation of surface hydroxyl group on metal (B).

human body is relatively alkaline.

The concentration of the surface hydroxyl group on the (100), (110), and (111) planes of single-crystalline zirconia $^{59)}$ and Y-TZP ${ }^{60)}$ increases after immersion in water. The (110) plane preferentially reacts with water molecules, which is explained by the oxygen atom position of the (110) crystalline plane. In addition, phosphate ions are incorporated in the zirconia surfaces in Hanks' solution. However, the numbers of hydroxyl and phosphate groups formed on the surface of Y-TZP are smaller than those formed on titanium. In addition, calcium ion is not confirmed on the Y-TZP surface. The above results are similar to those obtained for metallic zirconium $^{61)}$.

\section{Titanium}

Titanium is an excellent corrosion-resistant material. Ti element itself is extremely active, resulting in a low standard electrode potential of $-1.63 \mathrm{~V} v s$. NHE in the reaction $\mathrm{Ti} \rightarrow \mathrm{Ti}^{2+}+2 \mathrm{e}^{-}$. This activity induces chemical stability due to immediate stabilization by a reaction with the environment. The resultant stability leads to difficulty in smelting, a high corrosion resistance, and safety issues in the human body. The corrosion resistance of CP Ti is very high ${ }^{62-65)}$ because the Ti atom immediately reacts with water molecules in aqueous solutions and moisture in the air, and forms a very thin titanium oxide film on its surface. This oxide film is immediately repaired even when it is ruptured by scratching; hence, the reaction of the Ti atom with the external environment is inhibited, resulting in apparent inactivity of $\mathrm{CP} \mathrm{Ti}$ and $\mathrm{Ti}$ alloys. This property directly contributes to their corrosion resistance and safety. The surface oxide film on CP Ti mainly consists of amorphous or low-crystalline and non-stoichiometric $\mathrm{TiO}_{2}$. As a considerable portion of oxidized titanium remains as $\mathrm{Ti}^{2+}$ and $\mathrm{Ti}^{3+}$ in the surface oxide film, the oxidation process can only be fully completed on the uppermost part of the surface film.

One of the reasons for the excellent biocompatibility of titanium is the excellent corrosion resistance, which, however, is not a sufficient condition for biocompatibility. Even the best corrosion-resistant metal, $\mathrm{Au}$, is inferior in tissue compatibility. In addition, electric plating of platinum to $\mathrm{CP} \mathrm{Ti}$ improves the corrosion resistance but depletes bone formation ${ }^{66)}$, because the surface property of $\mathrm{CP} \mathrm{Ti}$ is shielded and the bone formation ability is prevented. These results reveal that hard-tissue compatibility is not induced only by the corrosion resistance. In other words, corrosion resistance is a necessary, but not sufficient, condition for biocompatibility; there are other contributing factors.

In case of $\mathrm{TiO}_{2}$, the PZC of rutile is 5.3 and that of anatase is $6.2^{57}$; therefore, $\mathrm{TiO}_{2}$ does not show an outstanding acid or basic property but shows almost a neutral property. The concentration of surface hydroxyl groups on $\mathrm{TiO}_{2}$ is relatively large -4.9-12.5 $\mathrm{nm}^{-256,67)}$. After immersion in an aqueous solution, this concentration or wettability increases, which promotes the adsorption of proteins such as integrin and cytokine.

The composition and chemical state of a surface oxide film vary according to the surrounding environment, while the film is macroscopically stable. A passive film undergoes continuous partial dissolution and reprecipitation in the electrolyte from the microscopic viewpoint. Hence, in this sense, the surface composition is always changing according to the environment ${ }^{68)}$. $\mathrm{CP} \mathrm{Ti}$ and $\mathrm{Ti}$ alloys easily form calcium phosphates on themselves in a biological environment and sulfite and sulfide, especially under a cell culture ${ }^{69-73)}$. CP Ti is stabilized after the formation of calcium phosphate in Hanks' solution ${ }^{61)}$. In addition, calcium and phosphorus are detected at the interface between $\mathrm{CP} \mathrm{Ti}$ and bone tissue $^{74-76)}$. One of the reasons for the excellent hardtissue compatibility in titanium may be its ability to form calcium phosphate. Bone screws and nails made of Ti alloys form callus during implantation; consequently, the bone is sometimes re-fractured when the devices are retrieved $^{77)}$. Therefore, when devices must be retrieved 
after healing, they are made of 316L-type stainless steel. This assimilation occurs due to the excellent hard tissue compatibility of Ti alloys. A proper surface treatment may inhibit bone formation and bonding of the Ti alloycontacting bone tissue.

\section{BACTERIAL ADHESION}

The adhesion of oral bacteria to zirconia in vitro is evaluated from the viewpoint of orthopedics ${ }^{78)}$. Zirconia reduces plaque formation on the implant surface, which leads to good healing and a successful implant treatment ${ }^{32)}$. Some difference in the inhibition of growth and adhesion of selected oral bacteria on titanium and zirconia in vitro were observed and the plaque formation on the zirconia surface might be less than that on the titanium surface ${ }^{79,80)}$. Zirconia showed a significantly lesser adhesion of bacteria than titanium in an in vivo study $^{81,82)}$. In the analysis of 20 healthy participants, titanium-related sites presented the highest total microbial count and higher counts of pathogenic species ${ }^{83)}$. Compared to titanium, zirconia abutments may represent a material surface less attractive for early plaque retention ${ }^{84)}$.

On the other hand, the bacterial adhesion to zirconia was similar to that to titanium ${ }^{79,82)}$. There was no significant difference in bacteria adhesion between titanium and zirconia in vitro when titanium and zirconia coating with saliva were incubated with Streptococcus sanguis $^{85)}$. Titanium- and zirconia-related surfaces are promptly colonized by a bacterial community similar to those found in the remaining adjacent teeth, suggesting a selective adhesion of different bacterial genotypes for titanium or zirconia surfaces ${ }^{86}$. In a biofilm formation test, zirconia implant surfaces with low surface roughness are comparable to titanium surfaces with respect to the initial bacterial adhesion and biofilm formation $^{87)}$. In addition, both titanium and zirconia groups presented similar microbial counts and diversity over time, and the microbiota was very similar to that colonizing the remaining teeth. Clinical findings were consistent with a healthy condition with no significant difference regarding marginal bone loss between zirconia and titanium $^{88)}$.

According to the above references, zirconia is superior or similar to inhibiting bacterial adhesion against titanium. Therefore, zirconia is an appropriate abutment of the implant from the viewpoint of bacterial adhesion.

\section{BONE FORMATION AND BONE BONDING}

CP Ti shows a unique property, "osseointegration," among metals, which is defined as the "formation of a direct interface between an implant and bone, without intervening soft tissue. No scar tissue, cartilage or ligament fibers are present between the bone and implant surface. The direct contact of bone and implant surface can be verified microscopically" ${ }^{89)}$. This concept generated and significantly accelerated studies on the reaction between hard tissue and $\mathrm{CP} \mathrm{Ti}$, followed by those on surface treatment. In this sense, the term "osseointegration" is invented for the CP Ti implant. Extensive research on the hard-tissue compatibility of Ti has been reported; introducing everything is outside the scope of this review, and hence, readers are directed to a book in which this is reviewed ${ }^{46)}$. The excellent hard-tissue compatibility of $\mathrm{CP} \mathrm{Ti}$ was confirmed by studies on the formation ability of calcium phosphate in simulated body fluids; evaluation of osteoblast activity and calcification; histological and molecular-biological evaluation of titanium implanted in animals, in terms of bone formation, bone contacting rate, and bone bonding strength; and clinical results. The above results revealed that, when CP Ti is implanted in bone, the surrounding tissue contacts the titanium surface in an early stage and the bone bonding strength is high. Important factors governing hard-tissue compatibility are the adhesion and proliferation of osteogenic cells because of factors such as surface morphology (roughness) and wettability. Bone formation occurs in the inflammatory response period, osteoblast induction period, and bone formation period. The surfaces of titanium implants and the titanium-bone interface reaction have been characterized to explain the importance of surface morphology, wettability, and energy for osseointegration ${ }^{90.91)}$. The surface of titanium implants stored for a long time after manufacturing becomes contaminated and the bone conduction ability decreases during storage ${ }^{92)}$.

On the other hand, research on zirconia dental implants has been reviewed ${ }^{32,93)}$. Most of the studies investigated bone-to-implant contact (BIC) around zirconia in rabbits, pigs, dogs, sheep, and rats, and showed that zirconia implants exhibit excellent $\mathrm{BIC}^{94)}$.

Several studies have revealed that zirconia implants show comparable osseointegration to titanium implants. When the BIC of zirconia implants was compared with those of titanium and alumina, there was no statistical difference among the BICs of the three types of implant ${ }^{95}$. In addition, no difference in osseointegration between the acid-etched zirconia and titanium implants was observed ${ }^{96-98)}$. The coated zirconia and titanium implants showed a higher removal torque than the machined zirconia implants, suggesting that surfacemodified zirconia implants can attain high stability in bones ${ }^{99}$. There is no significant influence of the evaluated zirconia and titanium on the outcomes of interest. Comparing different animal models, significant differences for the evaluated variables were found $^{100)}$. When four zirconia and four titanium implants were placed in New Zealand white male rabbits, the percentage of implant surface covered with bone was comparable for the two materials. A similar rate of bone apposition on zirconia- and surface-modified titanium implant surfaces during early healing was obtained $^{101)}$. Zirconia showed comparable biological responses of osteoblast-like cells to titanium for a short time during the cell culture period. Most genes related to cell adhesion and signal showed a similar expression level between titanium and zirconia ${ }^{102)}$. No significant 
Table 4 Method and results of review papers comparing properties of zirconia with those of titanium

\begin{tabular}{|c|c|c|c|}
\hline Title & $\begin{array}{l}\text { Author and } \\
\text { reference }\end{array}$ & Method & Conclusions \\
\hline
\end{tabular}

This review started with a PubMed search from 1975 to 2009. The inclusion criteria for articles were

Zirconia dental implants: A literature review

Zirconia in dental implantology: A review
Apratim et al., $2015^{32)}$

Pieralli et al., 2018 ${ }^{100)}$ investigations: A systematic review and metaanalysis
Biological effect of the abutment material on the stability of preimplant marginal bone levels: A systematic review and metaanalysis.
Özkurt

and

Kazazoğul, 2011 $1^{93)}$ as follows: (1) Articles were related to zirconia dental implants and (2) abstracts were obtained when the full texts could not be obtained. Articles on zirconia implants for orthopedic usage were excluded from the review.

Literature was searched to retrieve information about zirconia dental implant and studies were critically analyzed. PubMed database was searched for information about zirconia dental implant regarding mechanical properties, osseointegration, surface roughness, biocompatibility, and soft tissue health around it. The literature search was limited to English language articles published from 1975 to 2015.

Data on the osseointegration rate were extracted considering BIC, removal torque analysis (RTQ), and push-in tests. Meta analyses were conducted using multilevel multivariable mixedeffect linear regression models. The Sidak method was used in case of multiple testing. Sources. An electronic screening of the literature (MEDLINE/Pubmed, Cochrane Library and Embase) and a supplementary manual search were performed.

A protocol was developed to answer the following question: "What is the effect of the abutment material on stability and health of the periimplant hard tissues?" Randomized controlled trials (RCTs), controlled clinical trials

Sanz-

Sánchez

et al.,

$2018^{103)}$
(CCTs), or prospective case series (CS) with at least 6 months of follow-up were included, and meta-analyses were performed to compare abutment materials with titanium and to evaluate the impact of various abutment materials on bone changes (primary outcome), probing depth, plaque levels, and pre-implant mucosal inflammation.
On the basis of available peer-reviewed data, osseointegration of zirconia dental implants may be comparable with that of titanium implants. They were also found to have low, well-distributed, and similar stress distribution when compared to titanium implants. The surface roughness of zirconia was found to be comparable to that of titanium implants.

Some of the properties of zirconia seem to be suitable for making it an ideal dental implant, such as biocompatibility, osseointegration, favorable soft-tissue response, and esthetics due to light transmission and its color. It was also found that most of the studies on zirconia dental implants are short-term studies and there is a need for more long-term clinical trials to prove that zirconia is worth enough to replace titanium as a biomaterial in dental implantology.

No significant influence of the evaluated bulk materials on the outcomes of interest could be detected. When comparing different animal models, significant differences for the evaluated variables could be found. These results might be of interest for the design of further animal investigations.

Twenty-nine publications from 33 investigations were included. Results from the meta-analyses demonstrated no significant differences between the different abutment materials when compared to titanium, in regard to the changes in marginal bone levels. The meta-analysis reported a significantly greater increase in bleeding on probing for titanium compared to zirconia abutments. When evaluating the behavior of each material different from titanium, there was a significant bone loss over time for all individual materials except for titanium nitride. This systematic review has shown that the abutment material has minimal impact on marginal bone levels when compared to the standard titanium. 
Table 4 continued

\begin{tabular}{|c|c|c|c|}
\hline Title & $\begin{array}{l}\text { Author and } \\
\text { reference }\end{array}$ & Method & Conclusions \\
\hline $\begin{array}{l}\text { Is zirconia a } \\
\text { viable alternative } \\
\text { to titanium for } \\
\text { oral implant? A } \\
\text { critical review }\end{array}$ & $\begin{array}{l}\text { Sivaraman } \\
\text { et al., } \\
2018^{15)}\end{array}$ & $\begin{array}{l}\text { The literature search for articles } \\
\text { in PubMed and Cochrane Library } \\
\text { database from } 1990 \text { till December } \\
2016 .\end{array}$ & $\begin{array}{l}\text { Zirconia implants are a promising } \\
\text { alternative to titanium with a superior } \\
\text { soft-tissue response, biocompatibility, } \\
\text { and esthetics with comparable } \\
\text { osseointegration. However, further long- } \\
\text { term longitudinal and comparative clinical } \\
\text { trials are required to validate zirconia as a } \\
\text { viable alternative to the titanium implant. }\end{array}$ \\
\hline $\begin{array}{l}\text { Zirconia } \\
\text { compared to } \\
\text { titanium dental } \\
\text { implants in } \\
\text { preclinical } \\
\text { studies-A } \\
\text { systematic } \\
\text { review and meta- } \\
\text { analysis }\end{array}$ & $\begin{array}{l}\text { Roehling } \\
\text { et al., } \\
2019^{113)}\end{array}$ & $\begin{array}{l}\text { In March 2017, electronic } \\
\text { (MEDLINE, EMBASE) and hand } \\
\text { search was performed to identify } \\
\text { preclinical studies comparing } \\
\text { zirconia and titanium implants. } \\
\text { Primary outcomes were BIC, RTQ, } \\
\text { and push-in (PI) measurements. } \\
\text { Secondary outcomes included } \\
\text { biologic width (BW) dimensions. }\end{array}$ & $\begin{array}{l}\text { Zirconia and titanium implants } \\
\text { demonstrate a similar soft and hard } \\
\text { tissue integration capacity. However, } \\
\text { titanium tended to show a faster initial } \\
\text { osseointegration process compared to } \\
\text { zirconia. Importantly, not only material } \\
\text { characteristics but predominantly } \\
\text { animal species and study protocols can } \\
\text { significantly influence the outcomes. }\end{array}$ \\
\hline $\begin{array}{l}\text { Zirconia } \\
\text { abutments in the } \\
\text { anterior region: A } \\
\text { systematic review } \\
\text { of mechanical } \\
\text { and esthetic } \\
\text { outcomes }\end{array}$ & $\begin{array}{l}\text { Naveau } \\
\text { et al., } \\
2019^{124)}\end{array}$ & $\begin{array}{l}\text { An electronic search was conducted } \\
\text { in Medline (PubMed) for studies } \\
\text { on zirconia abutments. All clinical } \\
\text { studies with at least a 1-year } \\
\text { follow-up and case series ( }>5 \\
\text { abutments) published after } 2013 \\
\text { were included. Mechanical and } \\
\text { esthetic outcomes were collected. }\end{array}$ & $\begin{array}{l}\text { No difference was found between } \\
\text { prefabricated and custom abutments } \\
\text { or internal and external implant } \\
\text { connections regarding fractures or screw } \\
\text { loosening. All authors reported "good to } \\
\text { excellent" esthetic integration in terms of } \\
\text { restorations and soft-tissue color and the } \\
\text { presence and height of papillae. The most } \\
\text { difficult esthetic parameters to achieve } \\
\text { were root convexity, soft-tissue color, and } \\
\text { texture and level of mucosa. }\end{array}$ \\
\hline
\end{tabular}

difference between zirconia and titanium was observed regarding changes in the marginal bone levels. A zirconia abutment had minimal impact on marginal bone levels when compared to the standard titanium ${ }^{103)}$. Collagen fiber orientation was similar, regardless of the implant material, demonstrating a predominantly parallel or parallel-oblique pattern ${ }^{104)}$. On the basis of the available peer-reviewed data, the osseointegration of zirconia dental implants may be comparable with that of titanium implants ${ }^{93)}$.

On the other hand, some papers have demonstrated the preference of zirconia over titanium. Bone healing around zirconia implants was found to be relatively more than that around titanium implants ${ }^{105)}$. A similar rate of bone apposition on zirconia and surface-modified titanium implant surfaces during early healing was found when a histological examination of early bone apposition around zirconia dental implants at 2 and 4 weeks after insertion was compared to that of surfacemodified titanium implants ${ }^{106)}$.

On the contrary, several studies have supported the excellence of titanium for osseointegration compared to zirconia. The removal torque values of machined zirconia implants, sandblasted zirconia implants, and acidetched titanium implants were evaluated. Machined zirconia showed the least removal torque value, while acid-etched titanium implants showed the highest value, followed by sandblasted zirconia implants ${ }^{107)}$. Comparing the biomechanical properties of six types of implant surfaces, the removal torque value of zirconia implants was the least ${ }^{108}$. Zirconia implants are not currently recommended because their clinical use lacks scientific support ${ }^{109)}$. Compared to titanium, zirconia is inferior in osseointegration and requires improvement by surface modification. The removal torque value of zirconia implants was improved after surface modification, but was not more than that of titanium implants. It is known that Y-TZP is not capable of bonding chemically with hard tissues directly ${ }^{110,111)}$. The bone tissue response throughout the healing periods was characterized by a constant bone remodeling accompanied by resorption of the old bone in favor of the new bone formation at both titanium and zirconia implants. Surface roughness had a positive effect on BIC, although not showing statistical significance. Due to the poor survival rate, the experimental zirconia implants investigated may not be suitable for clinical use ${ }^{112)}$. Titanium tended to show a faster initial osseointegration process compared to zirconia $^{113)}$. At 12 weeks, the only significant difference in the removal torque was between titanium and 
sandblasted zirconia, with titanium demonstrating the higher value ${ }^{50)}$. The adhering U2OS osteoblast cells were significantly more displaced from differently modified titanium surfaces by challenging sub-gingival pathogens than those from Ti-Zr alloys and zirconia variants ${ }^{114}$. BMP4 and 7 are more expressed in osteoblasts exposed to the CP Ti surface, suggesting that the CP Ti surfaces can provide some advantages to immediate load implantology ${ }^{115)}$.

Although titanium shows superior osseointegrative property than zirconia, zirconia shows almost the same gratitude of osseointegration after surface treatment. Surface roughness is the most predominant factor governing osseointegration. The methods and results of review papers corresponding to this review are summarized in Table 4. Most of them revealed that titanium is superior for osseointegration than zirconia, followed by the comments that more studies are necessary.

\section{SOFT-TISSUE ADHESION}

The adhesion of soft tissue to materials is necessary when they are used as abutments in dental implant systems. If the adhesion between the device and soft tissue is not sufficient, bacteria can invade the interface between the junctional epithelium; this results in irritation between the device and bacteria, thereby causing the implant to loosen, shake, and fall out.

Some studies have revealed that soft tissue adhesion to zirconia is comparable to that to titanium. Zirconia abutments were attached to soft tissues in a clinical study and there was no loosening and fracture of the abutment screw over three years ${ }^{116)}$. The collagen fiber orientation around zirconia implants was parallel to the implant surface, similar to that in the case of titanium ${ }^{104)}$. Zirconia showed similar probing depth to titanium ${ }^{79}$. The distance from the peri-implant mucosa to the apical termination of the barrier epithelium for zirconia was less than that for titanium, and zirconia had less mucosal color change as compared to titanium. On the other hand, healing of soft tissue around the titanium abutment was better than that around the zirconia abutment ${ }^{117,118}$. There was no significant difference in the soft tissue response between zirconia and titanium abutments ${ }^{119)}$. When zirconia and titanium implants were inserted in the extraction sites of monkeys, both implants showed the same peri-implant soft tissue dimensions ${ }^{120)}$.

On the other hand, some studies have demonstrated the merit of zirconia to soft tissue compatibility. Zirconia showed favorable interaction with the soft tissue ${ }^{32}$. A high-wettability surface of zirconia using a $\mathrm{CO}_{2}$ laser is important to cell adhesion ${ }^{82}$. In addition, zirconia showed superior soft tissue integration compared to titanium for an oral implant in terms of reaction to bacteria ${ }^{15,121)}$. The presence of more remodeling and/ or inflammatory phenomena around titanium implant abutments than those around zirconia abutments of a different design was observed during the early stages but not at 1 year ${ }^{122)}$.
One study showed the merit of titanium for soft tissue adhesion. Smooth titanium implant surfaces provide the best opportunities for a soft tissue seal to form on bacterially contaminated implant surfaces ${ }^{123}$.

\section{CONCLUSIONS}

The mechanical property of titanium is superior to that of zirconia, while some studies have shown that zirconia is acceptable for use as a dental implant, especially for abutment. The current surface treatment research has been focusing on inhibiting bacterial adhesion and improving osseointegration and soft tissue adhesion, which make it difficult to evaluate the properties of materials themselves without surface treatment. The osseointegration of titanium is superior to that of zirconia itself without surface treatment, while surface morphology is a more important factor for osseointegration than surface composition. In the case of bacterial adhesion, zirconia is superior to titanium, suggesting that it is suitable for abutments. On the other hand, both materials show similar property for soft tissue adhesion. We would like to demonstrate again that all materials have both advantages and disadvantages, so optimal materials must be selected according to the purpose.

\section{ACKNOWLEDGMENTS}

The projects "Creation of Life Innovation Materials for Interdisciplinary and International Researcher Development" and "Cooperative project amount medicine, dentistry, and engineering for medical innovation -Construction of creative scientific research of the viable material via integration of biology and engineering" were supported by the Ministry of Education, Culture, Sports, Science and Engineering, Japan.

\section{REFERENCES}

1) Audley JA. The use of zirconia as a refractory material. Nature 1917; 99: 375-376.

2) Scott HG. Phase relationships in the zirconia-yttria system. J Mater Sci 1975; 10: 1527-1535.

3) Turp V, Tuncelli B, Sen D, Goller G. Evaluation of hardness and fracture toughness, coupled with microstructural analysis, of zirconia ceramics stored in environments with different $\mathrm{pH}$ values. Dent Mater J 2012; 31: 891-902.

4) Lange FF. Transformation toughening. J Mater Sci 1982; 17: 225-234.

5) Ashizuka M, Kiyohara H, Ishida E, Kuwabara M, Kubota Y, Tsukidate T. Fatigue behavior of $\mathrm{Y}_{2} \mathrm{O}_{3}$-partially stabilized zirconia. Yogyo-Kyokai-Shi 1986; 94: 432-439. (in Japanese)

6) Denry I, Kelly JR. State of the art of zirconia for dental applications. Dent Mater 2008; 24: 299-307.

7) Piconi C, Maccauro G. Zirconia as a ceramic biomaterial. Biomaterials 1999; 20: 1-25.

8) Gupta TK, Bechtold JH, Kuznicki RC, Cadoff LH, Rossing BR. Stabilization of tetragonal phase in polycrystalline zirconia. $\mathrm{J}$ Mater Sci 1977; 12: 2421-2426.

9) Gupta TK, Lange FF, Bechtold JH. Effect of stress-induced phase transformation on the properties of polycrystalline zirconia containing metastable tetragonal phase. J Mater Sci 
1978; 13: 1464-1470.

10) Pascual C, Jurado JR, Duran P. Electrical behavior of dopedyttria stabilized zirconia ceramic materials. J Mater Sci 1983; 18: 1315-1322.

11) Gravie RC, Hannink RH, Pascoe RT. Ceramic steel? Nature 1975; 258: 703-704.

12) Hulbert SF. The use of alumina and zirconia in surgical implants. In: Hench LL. editor. An introduction to bioceramics. Singapore: World Scientific; 1993. pp. 25-40.

13) Clarke IC, Manaka M, Green DD, Williams P, Pezzotti G, Kim YH, et al. Current status of zirconia used in total hip implants. J Bone Joint Surg Am 2003; 85: 73-84.

14) Helmer JD, Driskell TD. Research on bioceramics. Symp. on Use of Ceramics as Surgical Implants. SC, USA; Clemson University: 1969.

15) Sivaraman K, Chopram A, Narayan AI, Balakrishnan D. Is zirconia a viable alternative to titanium for oral implant? A critical review. J Prosthodont Res 2018; 62: 121-133.

16) Ueda K. Zirconia powder. J Dent Mater 2016; 35: 261-264. (in Japanese)

17) Bothe RT, Beaton LE, Davenport HA. Reaction of bone to multiple metallic implants. Surg Gynec Obsbtet 1940; 71: 598-602.

18) Leventhal GS. Titanium, a metal for surgery. J Bone Joint Surg Am 1951; 33A: 473-474.

19) Beder OE, Stevenson JK, Jones TW. A further investigation of the surgical application of titanium metal in dogs. Surgery 1957; 41: 1012-1015.

20) Williams DF. Titanium and Titanium Alloys. In: Williams DF, editor. Biocompatibility of Clinical Implant Materials. Boca Raton, FL, USA: CRS Press; 1982. pp. 10-44.

21) Williams DF. Biological Effects of Titanium. In: Williams DF, editor. Systematic Aspects of Biocompatibility. Boca Raton, FL, USA: CRS Press; 1982. pp. 170-177.

22) Pillar RM, Weatherly GC. Development in Implant Alloys. In: Williams DF, editor: Clinical Reviews in Biocompatibility, Vol. 1, Boca Raton, FL, USA: CRC Press; 1982. pp. 371-473.

23) Semlitsch M, Staub F, Weber H. Titanium-aluminumniobium alloy development for biocompatible, high strength surgical implants. Biomed Tech 1985; 30: 334-339.

24) Rao VB, Houska CR. Kinetics of the phase-transformation in a Ti-15Mo-5Zr-3Al alloy as studied by X-ray-diffraction. Metal Trans A 1979; 10: 355-358.

25) Wang K, Gustavson L, Dumbleton J. Low modulus, high strength, biocompatible titanium alloy for medical implants. In: Froes FH, Caplan HL, editors. Titanium '92: Science and Technology, Warrenda, PA, USA: TMS; 1993. pp. 2697-2704.

26) Zardiackas LD, Mitchell DW, Disegi JA. Characterization of Ti-15Mo beta titanium alloy for orthopaedic implant applications. In: Browns SA, Lemons JE, editors. Medical Applications of Titanium and Its Alloys, West Conshohoken, PA, USA: ASTM; 1996. pp. 60-75.

27) Fanning JC. Properties and processing of a new metasatable beta titanium alloy for surgical implant applications. In: Blenkinsop PA, Evans WJ, Flower H, editors. Titanium '95: Science and Technology, Cambridge, UK: The University Press; 1996. pp. 1800-1807.

28) Kuroda D, Niinomi M, Morinaga M, Kato Y, Yashiro T. Design and mechanical properties of new $\mathrm{b}$ type titanium alloys for implant materials. Mater Sci Eng A 1998; A243: 244-249.

29) Niinomi M. Design and development of metallic biomaterials with biological and mechanical biocompatibility. J Biomed Mater Res Part A 2019; 107A: 944-954.

30) Waterstrat RM, Rupp NW, Franklin O. Production of a cast titanium-base partial denture. J Dent Res 1978; 57, Special Issue, 254

31) Miura I, Ida K, editors. Titanium in Dentistry. Tokyo, Japan: Quintessence; 1988. (in Japanese)

32) Apratim A, Eachempati P, Salian KKK, Singh V, Chhabra S,
Shah S. Zirconia in dental implantology: A review. J Int Soc Prev Community Dent 2015; 5: 147-156.

33) Piconi C, Maccauro G. Zirconia as a ceramic biomaterial. Biomaterials 1999; 20: 1-25.

34) Chai J, Chu FC, Chow TW, Liang BM. Chemical solubility and flexural strength of Zirconia- based ceramics. Int $\mathrm{J}$ Proshodont 2007; 20: 587-595.

35) Yilmaz H, Aydin C, Gul BE. Flexural strength and fracture toughness of dental core ceramics. J Prosthet Dent 2007; 98: 120-128.

36) Qeblawi DM, Muñoz CA, Brewer JD, Monaco EA Jr. The effect of zirconia surface treatment on flexural strength and shear bond strength to a resin cement. J Prosthet Dent 2010; 103: 210-220.

37) KohalRJ, Wolkewitz M, Tsakona A. The effects of cyclic loading and preparation on the fracture strength of zirconium-dioxide implants: An in vitro investigation. Clin Oral Implants Res 2011; 22: 808-814.

38) Chevalier J, Gremillard L, Virkar AV, Clarke DR. The tetragonal-monoclinic transformation in zirconia: Lessons learned and future trends. J Am Ceram Soc 2009; 92: 19011920.

39) Suresh A, Mayo MJ, Porter WD, Rawn CJ. Crystallite and grain-size-dependent phase transformations in Yttria-Doped zirconia. J Am Ceram Soc 2003; 86: 360-362.

40) Garvie RC, Hannink RH, Pascoe RT. Ceramic steel? Nature 1975; 258: 703-704.

41) Sato T, Shimada M. Transformation of Yttria-Doped tetragonal $\mathrm{ZrO}_{2}$ polycrystals by annealing in water. $\mathrm{J} \mathrm{Am}$ Ceram Soc 1985; 68: 356-359.

42) Chevalier J. What future for zirconia as a biomaterial? Biomaterials 2006; 27: 535-543.

43) Deville S, Chevalier J, Gremillard L. Influence of surface finish and residual stresses on the ageing sensitivity of biomedical grade zirconia. Biomaterials 2000; 27: 2186-2192.

44) Watanabe M, Iio S, Fukuura I. Ageing behaviour of Y-TZP. In: Claussen N, Ruhle M, Heuer AH, editors. Science and Technology of Zirconia II (Advances in Ceramics) Vol. 12. Columbus, OH, USA: The American Ceramic Society; 1984. pp. 391-398.

45) Att $\mathrm{W}$, Grigoriadou $\mathrm{M}$, Strub JR. $\mathrm{ZrO}_{2}$ three-unit fixed partial dentures: Comparison of failure load before and after exposure to a mastication simulator. J Oral Rehabil 2007; 34: 282-290.

46) Brunette DM, Tenvall P, Textor M, Thomsen P, editors. Titanium in medicine. Berlin, Germany: Springer; 2001.

47) Leyens C, Peters M, editors. Titanium and titanium alloys, Köln, Germany: Wiley-VCH; 2003.

48) Foonq JK, Judqu RB, Palamara JE, Swain MV. Fracture resistance of titanium and zirconia abutments: an in vitro study. J Prosthet Dent 2013; 109: 304-312.

49) Schliephake H, Hefti T, Schlottig F, Gédet P, Staedt H. Mechanical anchorage and peri-implant bone formation of surface-modified zirconia in minipigs. J Clin Periodontol 2010; 37: 818-828.

50) Hoffmann O, Angelov N, Zafiropoulos GG, Andreana S. Osseointegration of zirconia implants with different surface characteristics: an evaluation in rabbits. Int $\mathrm{J}$ Oral Maxillofac Implant 2012; 27: 352-358.

51) Inokoshi M, Minakuchi S. Bond strategy for zirconia ceramics. J J Dent Mater 2016; 35: 265-268. (in Japanese)

52) Cooper FL, Stanford C, Feine J, McGuire M. Prospective assessment of CAD/CAM zirconia abutment and lithium disilicate crown restorations: 2.4 year results. J Prosthodont Dent 2016; 116: 33-39.

53) Hao L, Lawrence J, Chian KS. Osteoblast cell adhesion on a laser modified zirconia based bioceramic. J Mater Sci Mater Med 2005; 16: 719-726.

54) Miyake N, Miura T, Tanabe K, Hisanaga R, Yamashita S, 
Sato T, et al. Effect of physicochemical surface modifications on bovine serum albumin adsorption to tetragonal zirconia polycrystal in vitro through the change of the zeta potential. J Oleo Sci 2016; 65: 1003-1010.

55) Boehm HP. Functional groups on the surfaces of solids. Angew Chem 1966; 5: 533-544.

56) Boehm HP. Acidic and basic properties of hydroxylated metal oxide surfaces. Discuss Faraday Soc 1971; 52: 264-289.

57) Parfitt GD. The surface of titanium dioxide. Prog Surf Membr Sci 1976; 11: 181-226.

58) Muhammad S, Hussain ST, Waseem M, Naeem A, Hussain J, Tariq Jan M. Surface charge properties of zirconium oxide. Iran J Sci Technol A 2012; A4: 481-486.

59) Oishi M, Tsutsumi Y, Chen P, Ashida M, Doi H, Hanawa T. Surface changes of yttria-stabilized zirconia in water and Hanks solution characterized using XPS. Surf Interface Anal 2018; 50: 587-591.

60) Oishi M, Tsutsumi Y, Chen P, Nakaishi M, Ashida M, Doi $\mathrm{H}$, et al. Surface characterization of commercially available yttria-stabilized tetragonal zirconia polycrystalline in water and Hanks' solution using XPS. Dent Mater J 2019; 38: 496504.

61) Tsutsumi Y, Nishimura D, Doi H, Nomura N, Hanawa T. Difference in surface reactions between titanium and zirconium in Hanks' solution to elucidate mechanism of calcium phosphate formation on titanium using XPS and cathodic polarization. Mater Sci Eng C 2009; 29: 1702-1708.

62) Nakayama Y, Yamamuro T, Kotoura Y, Oka M. In vivo measurement of anodic polarization of orthopaedic implant alloys: comparative study of in vivo and in vitro experiments. Biomaterials 1989; 10: 420-414.

63) Asri RIM, Harun WSW, Samykano M, Lah NAC, Ghani SAC, Tarlochan F, et al. Corrosion and surface modification on biocompatible metals: A review. Mater Sci Eng C 2017; 77: 1261-1274.

64) Manam NS, Harum WSW, Shri DNA, Ghani SAC, Kurniawan T, Ismail MH. Study of corrosion in biocompatible metals for implants: A review. J Alloys Compd 2017; 701: 698-715.

65) Eliaz N. Corrosion of metallic biomaterials: A Review. Materials 2019; 12: 407.

66) Itakura $\mathrm{Y}$, Tajima $\mathrm{T}$, Ohoke S, Matsuzawa J, Sudo H, Yamamoto S. Osteocompatibility of platinum-plated titanium assessed in vitro. Biomaterials 1989; 10: 489-493.

67) Westall J, Hohl H. A comparison of electrostatic models for the oxide/solution interface. Adv Colloid Interface Sci 1980; 12: 265-294.

68) Kelly EJ. Electrochemical behavior of titanium. Mod Aspect Electrochem 1982; 14: 319-424.

69) Hanawa T, Ota M. Calcium phosphate naturally formed on titanium in electrolyte solution. Biomaterials 1991; 12: 767 774.

70) Hanawa T, Ota M. Characterization of surface-film formed on titanium in electrolyte using XPS. Appl Surf Sci 1992; 55: 269-276.

71) Healy KE, Ducheyne P. The mechanisms of passive dissolution of titanium in a model physiological environment. J Biomed Mater Res 1992; 26: 319-338.

72) Serro AP, Fernandes AC, Saramago B, Lima J, Barbosa MA. Apatite desorption on titanium surfaces - The role of albumin adsorption. Biomaterials 1977; 18: 963-968.

73) Hiromoto S, Hanawa T, Asami K. Composition of surface oxide film of titanium with culturing murine fibroblasts L929. Biomaterials 2004; 25: 979-986.

74) Sundgren JE, Bodo P, Lundstrom I. Auger electron spectroscopic studies of the interface between human tissue and implants of titanium and stainless steel. J Colloid Interface Sci 1986; 110: 9-20.

75) Esposito M, Lausmaa J, Hirsch JM, Thomsen P. Surface analysis of failed oral titanium implants. J Biomed Mater Res
1999; 48: 559-568.

76) Sundell G, Dahlin C, Andersson M, Thuvander M. The boneimplant interface of dental implants in humans on the atomic scale. Acta Biomater 2017; 48: 445-450.

77) Sanderson L, Ryan W, Turner PG. Complications of metalwork removal injury. Injury 1992; 23: 29-30.

78) Hisbergues M, Vendeville S, Vendeville P. Zirconia: Established facts and perspectives for a biomaterial in dental implantology. J Biomed Mater Res B Appl Biomater 2009; 88: 519-529.

79) van Brakel R, Cune MS, van Winkelhoff AJ, de Putter C, Verhoeven JW, van der Reijden W. Early bacterial colonization and soft tissue health around zirconia and titanium abutments: An in vivo study in man. Clin Oral Implants Res 2011; 22: 571-577.

80) Re D, Pellegrini G, Francinetti P, Augusti D, Rasperini G. In vivo early plaque formation on zirconia and feldspathic ceramic. Minerva Stomatol 2011; 60: 339-348.

81) Rimondini L, Cerroni L, Carrassi A, Torricelli P. Bacterial colonization of zirconia ceramic surfaces: An invitro and in vivo study. Int Oral Maxillofac Implants 2002; 17: 793-798.

82) Scarano A, Piattelli M, Caputi S, Favero GA, Piattelli A. Bacterial adhesion on commercially pure titanium and zirconium oxide disks: An in vivo human study. J Periodontol 2004; 75: 292-296.

83) Nascimento C, Pita MS, Santos ES, Monesi N, Pedrazzi V, Albuquerque Jr RF, et al. Microbiome of titanium and zirconia dental implant abutments. Dent Mater 2016; 32: 93-101.

84) Nakamura K, Kanno T, Mikkeding P, Ortengren U. Zirconia as a dental implant abutment materials: A systematic review. Int J Prosthodont 2010; 23: 299-309.

85) Lee BC, Jung GY, Kim DJ, Han JS. Initial bacterial adhesion on resin, titanium and zirconia in vitro. J Adv Prosthodont 2011; 3: 81-84.

86) de Freitas AR, de Oliveira Silva TS, Ribeiro RF, de Albuquerque Jr RF, Pedrazzi V, do Nascimento C. Oral bacterial colonization on dental implants reported with titanium or zirconia abutments: 6-month follow-up. Clin Oral Investig 2018; 22: 2335-2343.

87) Al-Ahmad A, Karygianni L, Wartenhorst MS, Bächle M, Hellwig E, Follo M, et al. Bacterial adhesion and biofilm formation on yttria-srtabilized, tetragonal zirconia and titanium oral implant materials with low surface roughness —an in situ study. J Med Microbiol 2016; 65: 596-604.

88) Raffaini FC, Freitas AR, Silva TSO, Cavagioni T, Oliveira $\mathrm{JF}$, Albuquerque RF, et al. Genome analysis and clinical implications of the bacterial communities in ealy biofilm formation on dental implants restored with titanium or zirconia abutments. Biofouling 2018; 34: 173-182.

89) Brånemark PI, Hansson BO, Adell R, Breine U, Lindström J, Hallén $\mathrm{O}$, et al. Osseointegrated implants in the treatment of the edentulous jaw. Experience from a 10-year period. Scand J Plastic Reconstruct Surg Hand Surg 1977; 11 (Suppl 16): $1-132$.

90) Rupp F, Liang L, Geis-Gerstorfer J, Scheideler L, Hüttig F. Surface characteristics of dental implants: A review. Dent Mater 2018; 34: 40-57.

91) Shah FA, Thomsen P, Palmquist A. A review of the impact of implant biomaterials on osteocytes. J Dent Res 2019; 97: 977-986.

92) Art W, Hori N, Takeuchi M, Ouyang J, Yang Y, Anpo M, et al. Time-dependent degradation of titanium osteoconductivity: an implication of biological aging of implant materials. Biomaterials 2009; 30: 5352-5363.

93) Özkurt Z, Kazazoğlu E. Zirconia dental implants: A literature review. J Oral Implantol 2011; 37: 367-376.

94) Siddiqi A, Khan AS, Zafar S. Thirty years of translational research in zirconia dental implants: A systematic review of the literature. J Oral Implantol 2017; 43: 314-326. 
95) Dubruille JH, Viguier E, Le Naour G, Dubruille MT, Auriol M, Le Charpentier Y. Evaluation of combinations of titanium, zirconia, and alumina implants with 2 bone fillers in the dog. Int J Oral Maxillofac Implants 1999; 14: 271-127.

96) Depprich R, Zipprich H, Ommerborn M, Mahn E, Lammers L, Handschel J, et al. Osseointegration of zirconia implants: An SEM observation of the bone-implant interface. Head Face Med 2008; 4: 25.

97) Gahlert M, Röhling S, Wieland M, Sprecher CM, Kniha H, Milz S. Osseointegration of zirconia and titanium dental implants: A histological andhistomorphometrical study in the maxilla of pigs. Clin Oral Implants Res 2009; 20: 1247-1253.

98) Gahlert M, Roehling S, Sprecher CM, Kniha H, Milz S, Bormann K. In vivo performance of zirconia and titanium implants: A histomorphometric study in mini pig maxillae. Clin Oral Implants Res 2012; 23: 281-286.

99) Sennerby L, Dasmah A, Larsson B, Iverhed M. Bone tissue responses to surface-modified zirconia implants: A histomorphometric and removal torque study in the rabbit. Clin Implant Dent Relat Res 2005; 7 (Suppl 1): S13-S20.

100) Pieralli S, Kohal RJ, Hernandez EL, Doerken S, Spies BC. Osseointegration of zirconia dental implants in animal investigations: A systematic review and meta-analysis. Dent Mater 2018; 34: 171-182

101) Hoffmann O, Angelov N, Gallez F, Jung RE, Weber FE. The zirconia implant-bone interface: A preliminary histologic evaluation in rabbits. Int J Oral Maxillofac Implants 2008; 23: 691-695.

102) Gong SH, Lee H, Pae A, Noh K, Shin YM, Lee JH, et al. Gene expression of MC3T3-E1 osteoblastic cells on titanium and zirconia surface. J Adv Prosthodont 2013; 5: 416-422.

103) Sanz-Sánchez I, Sanz-Martin I, de albornoz AC, Figuero E, Sanz M. Biological effect of the abutment material on the stability of peri-implant marginal bone levels: A systematic review and meta-analysis. Clin Oral Implants Res 2018; suppl.18: 124-144.

104) Tete S, Mastrangelo F, Bianchi A, Zizzari V, Scarano A. Collagen fiber orientation around machined titanium and zirconia dental implant necks: An animal study. Int J Oral Maxillofac Implants 2009; 24: 52-58.

105) Schultze-Mosgau S, Schliephake H, Radespiel-Tröger M, Neukam FW. Osseointegration of endodontic endosseous cones: Zirconium oxide vs titanium. Oral Surg Oral Med Oral Pathol Oral Radiol Endod 2000; 89: 91-98.

106) Hoffmann O, Angelov N, Gallez F, Jung RE, Weber FE. The zirconia implant-bone interface: A preliminary histologic evaluation in rabbits. Int J Oral Maxillofac Implants 2008; 23: 691-695.

107) Gahlert M, Gudehus T, Eichhorn S, Steinhauser E, Kniha H, Erhardt W. Biomechanical and histomorphometric comparison between zirconia implants with varying surface textures and a titanium implant in the maxilla of miniature pigs. Clin Oral Implants Res 2007; 18: 662-668.

108) Ferguson SJ, Langhoff JD, Voelter K, von Rechenberg B, Scharnweber D, Bierbaum S, et al. Biomechanical comparison of different surface modifications for dental implants. Int J Oral Maxillofac Implants 2008; 23: 1037-1046.
109) Kohal RJ, Att W, Bächle M, Butz F. Ceramic abutments and ceramic oral implants. An update. Periodontol 2000 2008; 47: 224-243.

110) Garvie RC, Urban D, Kennedy DR, McMeuer JC. Biocompatibility of magnesium partially stabilized zirconia (Mg-PSZ Ceramics). J Mat Sci 1984; 19: 3224-3228.

111) Tateishi $T$, Yunoki H. Research and development of advanced biomaterials and application to the artificial hip joint. Bull Mech Engr Lab1987; 45: 1-9.

112) Mihatovic I, Golubovic V, Becker J, Schwarz F. Bone tissue response to experimental zirconia implants. Clin Oral Invest 2017; 21: 523-532.

113) Roehling S, Schlegel KA, Woelfler H, Gahlert M. Zirconia compared to titanium dental implants in preclinical studies -A systematic review and meta-analysis. Clin Oral Implants Res 2019; 30: 365-395.

114) Zhao B, van der Mei HC, Rustema-Abbing M, Busscher HJ, Ren Y. Osteoblast integration of dental implant materials after challenge by sub-gingival pathogens; a co-culture study in vitro. Int J Oral Sci 2015; 7: 250-258.

115) Palmieri A, Pezzetti F, Brunelli G, Lo Muzio L, Scarano A, Scapoli L, et al. Short-period effects of zirconia and titanium on osteoblast MicroRNAs. Clin Implant Dent Relat Res 2008; 10: 200-205.

116) Fujisawa R, Kuboki Y. Preferential adsorption of dentin and bone acidic proteins on the (100) face of hydroxyapatite crystals. Biochim Biophys Acta 1991; 1075: 56-60.

117) Welander M, Abrahamsson I, Berglundh T. The mucosal barrier at implant abutments of different materials. Clin Oral Implants Res 2008; 19: 635-641.

118) Zembic A, Sailer I, Jung RE, Hämmerle CH. Randomizedcontrolled clinical trial of customized zirconia and titanium implant abutments for single-tooth implants in canine and posterior regions: 3-year results. Clin Oral Implants Res 2009; 20: 802-808.

119) van Brakel R, Meijer GJ, Verhoeven JW, Jansen J, de Putter C, Cune MS. Soft tissue response to zirconia and titanium implant abutments: An in vivo within-subject comparison. J Clin Periodontol 2012; 39: 995-1001.

120) Kohal RJ, Weng D, Bächle M, Strub JR. Loaded custom-made zirconia and titanium implants show similar osseointegration: An animal experiment. J Periodontol 2004; 75: 1262-1268.

121) Brönemark PI. The biologic origin of osseointegration. In: The osseointegration book: From calvarium to calcaneus. Berlin, Germany: Quintessence Books: 2005. p. 22.

122) Kumar Y, Jain V, Chauhan SS, Bharate V, Koli D, Kumar M. Influence of different forms and materials (zirconia and titanium) of abutments in peri-implant soft-tissue healing using matrix metalloproteinase-8: A randomized pilot study. J Prosthet Dent 2017; 118: 475-480.

123) Zhao B, van der Mei HC, Subbiahdoss G, de Vries J, RustemaAbbing M, Kuijer R, et al. Soft tissue integration versus early biofilm formation on different dental implant materials. Dent Mater 2014; 30: 716-727.

124) Naveau A, Rignon-Bret C, Wulfman C. Zirconia abutments in the anterior region: A systematic review of mechanical and esthetic outcomes. J Prosthet Dent 2019; 121: 775-781. 